\title{
Sediment destabilizing and stabilizing bio-engineers on tidal flats: cascading effects of experimental exclusion
}

\author{
Nils Volkenborn · Dylan Martin Robertson • \\ Karsten Reise
}

Received: 9 October 2007 / Revised: 16 March 2008 / Accepted: 7 April 2008 / Published online: 31 October 2008

(C) Springer-Verlag and AWI 2008

\begin{abstract}
Bioturbating lugworms (Arenicola marina) were excluded from $400 \mathrm{~m}^{2}$ plots of intertidal sand which initiated sequences of direct and indirect changes in the structure of the benthic community. The sessile, tube-building species Polydora cornuta and Lanice conchilega took advantage of the absence of lugworms and settled preferentially on lugworm exclusion plots. The protruding tubes provided attachment for an ephemeral development of algal tufts (Berkeleya colonies and Enteromorpha thalli) which in turn enhanced settlement of the juvenile drifting clams Mya arenaria and Macoma balthica. This causal chain of enhanced bivalve settlement in the presence of aboveground structures, like animal tubes and algae, on lugworm exclusion plots occurred in 2 years at different tidal zones with different tube builders, algae and juvenile clams. A significant response of $L$. conchilega in a year with relatively low lugworm abundances at the entire site suggests that not only the actual absence of large bioturbators was responsible for the establishment of tube-dwelling species, but also a cumulative change of the sediment in exclusion
\end{abstract}

Communicated by K. Reise.

N. Volkenborn $(\square) \cdot$ K. Reise

Alfred Wegener Institute for Polar and Marine Research, Wadden Sea Station Sylt, Hafenstrasse 43, 25992 List, Germany e-mail: nils.volkenborn@awi.de

D. M. Robertson

Department of Marine Science, University of Otago,

P.O. Box 56, Dunedin, New Zealand

Present Address:

N. Volkenborn

Department of Biological Sciences,

University of South Carolina, Columbia, SC 29208, USA

e-mail: nils@biol.sc.edu plots since the onset of the experiment. While the sediment on lugworm plots remained permeable, fine particles and organic matter accumulated at exclusion plots. It is suggested that these differences in sediment characteristics were the product of divergent benthic engineering by sediment destabilizing lugworms on control plots and sediment stabilizing species on exclusion plots. Cumulative changes of the sedimentary habitat and cascading effects in the benthic community may explain the persistence of patches that are dominated by either sediment stabilizing or destabilizing species in the assemblage mosaic of intertidal sediments.

Keywords Ecosystem engineering - Arenicola marina · Bioturbation · Sediment stabilizers $\cdot$ Sediment destabilizers

\section{Introduction}

Ecosystem engineers in marine soft sediments may be classified into two fundamental functional categories: bioturbators loosen the sedimentary fabric and destabilise sediments (Rhoads 1974; Brenchley 1981) while sedentary species, e.g. tubebuilders or seagrasses, stabilise sediments (Woodin 1981; Gallagher et al. 1983). Both, sediment destabilizing and sediment stabilizing engineers may have profound effects on the sedimentary habitat and the structures of benthic communities (Reise 2002), often making the environment less suitable for the ecologically different form (Woodin and Jackson 1979; Thayer 1983). As a result of these mobility-mode interactions, natural soft-bottom communities are often dominated by either mobile or sedentary species (review by Posey 1987). Numerous examples indicate this mutual exclusion of one mobility group by the other: dense aggregations of thalassinidean shrimps were found to exclude several sedentary species, such as bivalves (Peterson 1977), tube-building 
polychaetes (Posey 1986) or seagrasses (Siebert and Branch 2006). The same is true for bioturbating lugworms which inhibit tubicolous worms (Wilson 1981; Volkenborn and Reise 2007), amphipods (Flach 1992) and rooted plants (van Wesenbeeck et al 2007). On the other hand, dense aggregations of tube-building species or seagrasses may considerably reduce the abundances of burrowing species (e.g. Woodin 1981), while other sedentary species may be facilitated (Brenchley 1982; Bolam and Fernandes 2003). Furthermore, the size of individuals needs to be taken into account when evaluating the influence of relative mobilities on the composition of benthic communities. Large, active burrowers may considerably affect small sedentary species, but not necessarily large ones (Wilson 1981), while sedentary species may reduce the abundances of intermediate-sized burrowers but not necessarily the abundance of smaller and larger species (Posey 1987).

Functional group interactions may go far beyond direct sediment disruption through burrowing and binding of sediment by animal tubes or plant roots as suggested in the mobility-mode hypothesis (Brenchley 1982). Indirect, sediment-mediated effects of engineering activities may also affect the outcome of localised mobility-mode interactions. Bioirrigating infauna facilitates microbial degradation of organic material (Kristensen and Blackburn 1987) and decreases porewater nutrient concentrations (Huettel 1990) and microphytobenthic growth (Volkenborn et al. 2007a, b). Dense aggregations of tube-dwelling species may stabilise the sediment and increase the organic and fine particle content (Luckenbach 1986) and even dead biogenic structures, such as shell debris, may significantly alter habitat characteristics (Gutierrez et al. 2003). Sediment-mediated effects may thus considerably affect both, the food availability, and the sedimentary habitat characteristics for other benthic species.

Integration of mobility-mode interactions into the concept of ecosystem engineering (sensu Lawton and Jones 1993) will account for the complexity of benthic habitat transformations. Cumulative engineering of the sedimentary habitat may be a slow process, and many effects possibly are conditional, depending upon environmental constraints, such as sediment type or hydrodynamic exposure (Norkko et al. 2006). Large-scale, long-term field experiments thus may be the most appropriate tool to investigate under which environmental constraints spatial competition between alternate ecosystem engineers may unfold and if so, what are the consequences for the functioning of benthic communities.

This study focussed on intertidal benthic community dynamics induced by the permanent exclusion of the bioturbating polychaete Arenicola marina (L.), which is a widespread and abundant destabiliser of intertidal sandy sediments at northwest European coasts (Beukema 1976; Reise 1985, Cadée 1976). Arenicola marina lives in 20-40$\mathrm{cm}$ deep J-shaped burrows completed to a $\mathrm{U}$ by a vertical head shaft. Bioirrigation by the lugworm fluidises the sediment in the head shaft so that surface sediment slides down, is ingested by the worm, and defecated as a mound of coiled faecal strings at the sediment surface above the tail shaft (Riisgård and Banta 1998).

In 2002, a large-scale lugworm exclusion experiment was initiated. On six $400 \mathrm{~m}^{2}$ lugworm exclusion plots and corresponding lugworm populated plots, the sediment characteristics and the benthic community were monitored in subsequent years. Investigations of sediment and porewater properties in the presence/absence of A. marina revealed significant changes in habitat characteristics at lugworm exclusion plots (Volkenborn et al. 2007a, b). In summary, microphytobenthic biomass and the proportion of fine particles and associated organic material almost doubled on lugworm exclusion plots, sediment permeability decreased, and inorganic porewater nutrients and sulphide accumulated within the sediment. Benthic community response was variable in space and time, but the overall effect was that tubebuilding and burrow-constructing species (e.g. Pygospio elegans and Nereis diversicolor) took advantage of the absence of lugworms, while free burrowing species (e.g. Scoloplos cf. armiger) were not affected or even decreased in abundance (Volkenborn and Reise 2006, 2007).

Results from the large-scale lugworm exclusion experiment support the mobility mode hypothesis of mutual exclusion of functional different forms (Brenchley 1982). It is hypothesised that the underlying mechanisms go far beyond local and direct disturbance through burrowing and binding of sediment by animal tubes. Moreover, changes of the benthic habitat, originally induced by the exclusion of sediment destabilizing lugworms, may have been amplified by the bio-engineering of sediment stabilizing species. This paper will focus on developments in the benthic community on experimental plots one and 2 years after the experiment was started. Based on the observed species responses to the manipulative experimental treatments and on relevant literature, the mutual exclusion of sediment stabilizing and destabilizing bio-engineers on intertidal flats is proposed. Divergent trajectories may unfold, which contribute to the longevity of patches which are dominated by either mobility-mode. On a larger scale, these may generate a dynamic mosaic of assemblages in the marine benthos (Reise 1991).

\section{Materials and methods}

Study area and experimental design

A lugworm exclusion experiment was conducted on a sheltered, unvegetated intertidal sandflat in Königshafen, a tidal embayment at the northern tip of the island of Sylt in the North Sea $\left(55^{\circ} 02^{\prime} N ; 8^{\circ} 26^{\prime}\right.$ E). Details of the experimental 
set-up can be found in Volkenborn et al. (2007a) and Volkenborn and Reise (2006) and details of the study site are provided by Reise (1985) and Austen (1994). Exclusion of lugworms on replicated $(n=6) 400 \mathrm{~m}^{2}$ plots was achieved by inserting a $1-\mathrm{mm}$ meshed net at $10 \mathrm{~cm}$ depth into the sediment in spring 2002. The experiment was arranged in a 2 -factorial $(3 \times 2$ levels $)$ nested block design. Six experimental blocks were nested with respect to tidal height: three blocks around mid-tide level (emersion period 6-7 h per tide) with medium sand (grain size median 330-340 $\mu \mathrm{m}$ ) and three blocks near low-tide level (emersion period 3$4 \mathrm{~h}$ ) with a finer sediment (grain size median 200-220 $\mu \mathrm{m}$ ). Each experimental block consisted of three plots differing in treatment: exclusion $=$ buried net, control $=$ similarly dredged but left without a net, ambient $=$ untouched plot.

\section{Sampling of macrofauna and algae}

Sampling of macroinfauna was done by counting invertebrates retained on a 1-mm mesh sieve from eight cores of $100 \mathrm{~cm}^{2}$ and $10 \mathrm{~cm}$ depth randomly taken within each of the 18 experimental plots. Sampling was done every fourth month between April 2003 and August 2004. In August 2003 , eight additional subsamples of $10 \mathrm{~cm}^{2}$ from all experimental plots were sieved through a $250-\mu \mathrm{m}$ mesh to include small, juvenile polychaetes. Sampling was generally completed within one week and was done block-wise in order to include the effect of consecutive sampling into the block effect. Abundances of Lanice conchilega were additionally estimated by counting tube caps within one sub-quadrate of $10 \times 10 \mathrm{~cm}$ of eight quadrates of $0.25 \mathrm{~m}^{2}$. Colonies of the diatom Berkeleya rutilans (Trentepohl ex Roth) were counted in eight quadrates of $0.25 \mathrm{~m}^{2}$ on each experimental plot in April 2003. Abundances of algal strings of Enteromorpha spp. were not estimated, since it was not possible to identify individuals. As a measure of algal cover, the frequency in 25 sub-quadrates of $10 \times 10 \mathrm{~cm}$ in six randomly chosen quadrates of $0.25 \mathrm{~m}^{2}$ were determined in August 2004. Only green algal Enteromorpha strings that were anchored within sub-quadrates were considered. Additionally, green algal biomass was estimated from three representative samples of $100 \mathrm{~cm}^{2}$ within each plot as ash-free dry weight.

\section{Statistical analyses}

Abundances of macrofauna on experimental plots were analysed using two-factorial ANOVA. The effect of lugworm presence/absence was used as fixed factor (three levels: exclusion, control, ambient). Tidal position as second fixed factor was used to test the effect of tidal height (two levels: low intertidal, mid intertidal) and accounting for the significance of interaction effects of tidal height and lugworm presence/absence. Experimental blocks, nested in the tidal heights, were assessed as random factor to incorporate the spatial heterogeneity of the study site into the statistical analysis. Prior to analysis, data were tested for homogeneity of variances (Cochran's test) and log-transformed if required. Post hoc multiple means comparisons were performed using the Tukey-Kramer procedure at $\alpha=0.05$ significance level. In 2004, algae and Lanice frequency data were not homogenous. Due to the fact that $L$. conchilega and green algae almost exclusively occurred on lugworm exclusion plots in the low intertidal, statistical tests on factor effects were not performed in this case. In 2004, L. conchilega tubes and juvenile bivalves where counted within the same samples, allowing to test for localised species interactions by regression analysis. This was possible for the 2003 data since Polydora cornuta abundances were estimated from $10 \mathrm{~cm}^{2}$ samples while abundances of juvenile Macoma balthica were estimated from (different) $100 \mathrm{~cm}^{2}$ samples.

\section{Results}

Seasonal developments in the benthic community 2003

In spring 2003 colonies of the tuft-forming diatom B. rutilans developed mainly on experimental lugworm exclusion plots in the mid intertidal zone (Fig. 1a, b). Most of these diatom colonies were attached to tubes of the spinoid $P$. cornuta (Bosc). In April 2003 abundances of $P$. cornuta were threefold on lugworm exclusion plots compared to control and ambient plots in the mid intertidal zone (Fig. 2a) but overall, this polychaete was not significantly affected by the experimental treatment $\left(F_{2,8}=0.41\right.$; $P=0.68)$ nor by treatment $\times$ tidal height interaction $\left(F_{2,8}=2.03 ; P=0.19\right)$. In August 2003, when samples where sieved with $250 \mu \mathrm{m}$ mesh a significant treatment effect was found on abundances of $P$. cornuta $\left(F_{2,8}=7.37\right.$; $P=0.015)$ with significant higher abundances of $P$. cornuta on lugworm exclusion plots (Tukey $P<0.05$; Fig. 2b). The tuft-forming diatom B. rutilans appeared in March 2003, and until April algal tufts had reached a size of up to $10 \mathrm{~cm}$ and densities up to 50 colonies $\mathrm{m}^{-2}$ (Fig. 2c). Colony abundances were significantly affected by treatment $\times$ tidal height interaction $\left(F_{2,8}=28.76 ; P<0.001\right)$ indicating significant higher abundances of Berkeleya colonies on exclusion plots in the mid intertidal zone compared to other experimental treatments (Tukey $P<0.01$ ). In spring 2003 juveniles of $M$. balthica (L.) recruited to the study site. In August, they also reached highest densities on lugworm exclusion plots in the mid intertidal area (significant treatment $\times$ tidal height interaction, $F_{2,8}=4.53 ; P<0.01$ ). In the mid intertidal area average abundance of $M$. balthica 
Fig. 1 Lugworm exclusion plots with ephemeral algal growth. In spring 2003, colonies of the tuft-forming diatom Berkeleya rutilans were growing on exclusion plots in the mid intertidal (a) and most colonies noid polychaete Polydora cornuta (b). In summer 2004, green algal tufts were growing on lugworm exclusion plots in the low were attached to sand-tubes of the polychaete Lanice conchilega (d). Broken lines indicate the edges of lugworm exclusion plots were attached to tubes of the spiintertidal (c). Most algal strings
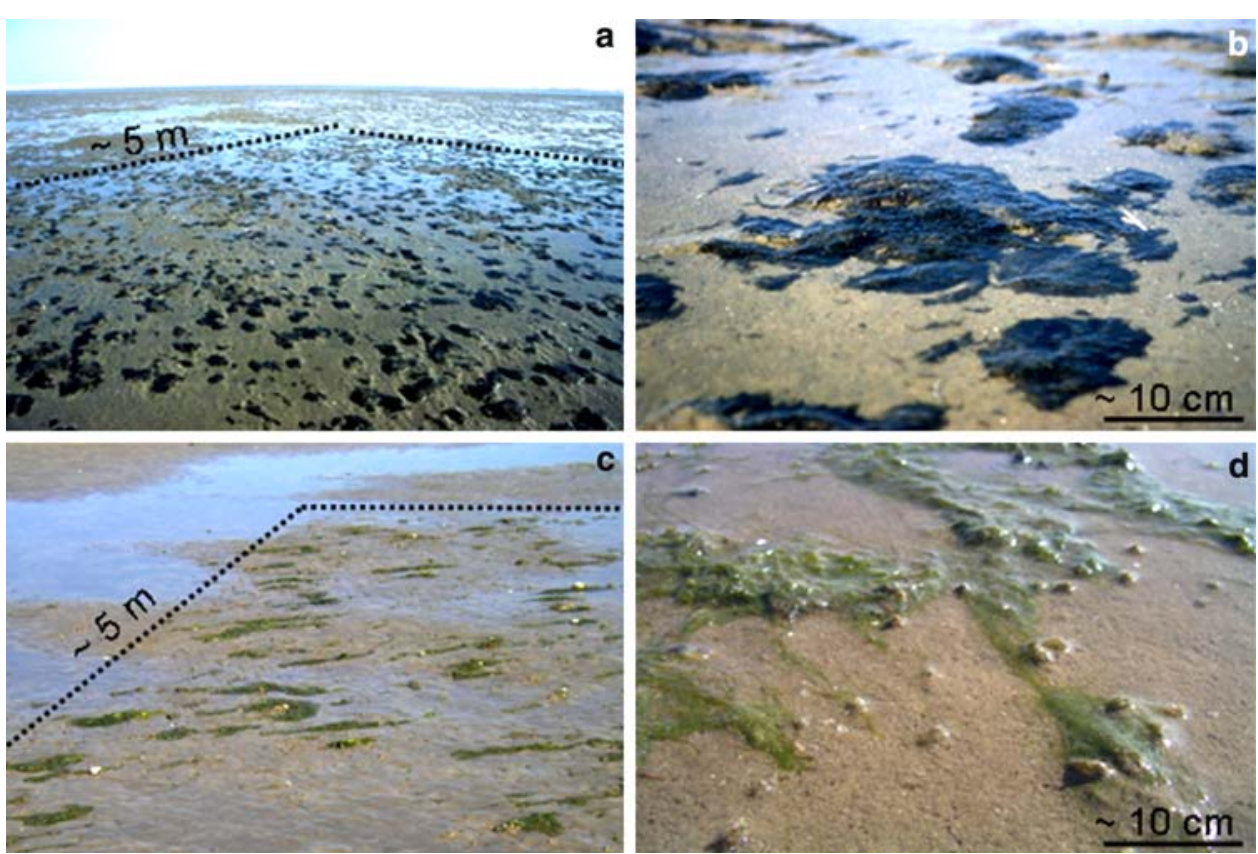

Fig. 2 Abundances of Polydora cornuta in April 2003 (a; sieved with $1,000 \mu \mathrm{m}$ mesh) and August 2003 (b; sieved with $250 \mu \mathrm{m}$ mesh), Berkeleya colonies (c) and juvenile Macoma balthica (d) on experimental plots in spring and summer 2003 (shown are means and SE $(n=6) ;$ Black = exclusion; Grey = control;

White $=$ ambient; asterisks indicate significant different treatments)
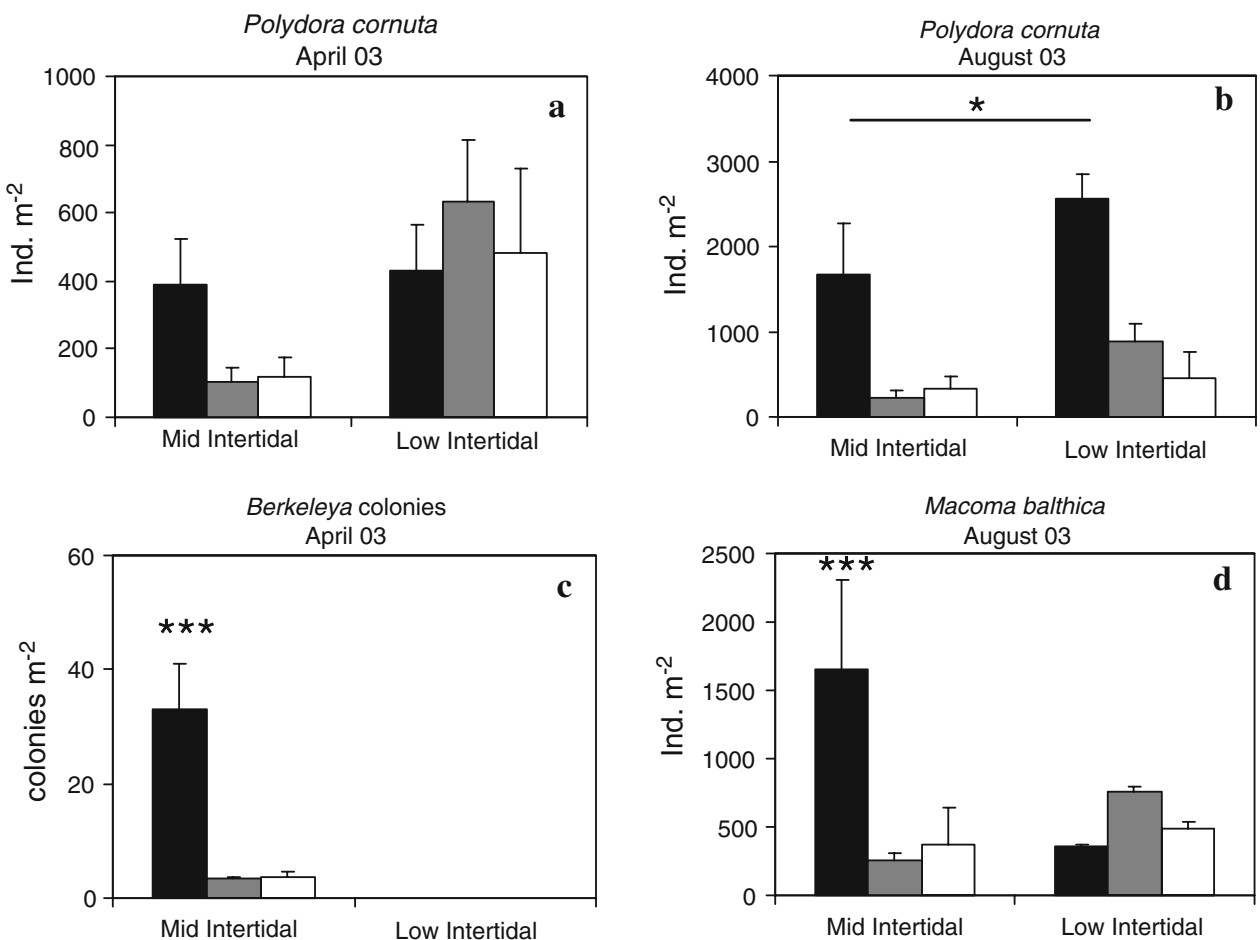

was 1,600 ind. $\mathrm{m}^{-2}$ on lugworm exclusion plots while abundances were below 500 ind. $^{-2}$ in all other experimental treatments (Fig. 2d).

Seasonal developments in the benthic community 2004

In summer 2004 green and red algae (Enteromorpha spp., Ulva spp., Polysiphonia spp.) developed on experimental plots in the low intertidal zone (Fig. 1c, d). Most of these algal strings were attached to tubes of the terebellid polychaete L. conchilega.

Lanice conchilega was first recorded on experimental plots in summer 2003. Until winter, abundances remained low ( $<5 \mathrm{~m}^{-2}$ averaged over all plots), but were already significantly affected by lugworm treatment $\left(F_{2,8}=12.47\right.$; $P<0.01)$ and tidal height $\left(F_{2,8}=16.36 ; P<0.01\right)$ with higher densities on lugworm exclusion plots and on plots in the low intertidal area (Tukey $P<0.01$ for both effects). 
Densities significantly increased from spring to summer 2004. In summer, L. conchilega was found almost exclusively on lugworm exclusion plots in the low intertidal area (Fig. 3a). In August 2004, L. conchilega reached average densities of 500 ind. $\mathrm{m}^{-2}$ on these plots. Algae occurred also almost exclusively on the lugworm exclusion plots (Fig. 3b). In the $10 \times 10 \mathrm{~cm}$ grid used to estimate algal cover, green algal frequency was about $90 \%$ and algae biomass was up to $20 \mathrm{~g}$ dry weight $\mathrm{m}^{-2}$. Two bivalve species (Mya arenaria (L.) and M. balthica) recruited to the low intertidal area of the experimental site in spring 2004. For both species, highest abundances were found within lugworm exclusion plots in the low intertidal area (Fig. 3 c, d). Within all 144 samples of $100 \mathrm{~cm}^{2}$, abundances of both species were significantly and positively correlated with the number of protruding Lanice tubes $\left(M\right.$. arenaria $r^{2}=0.755$; $P<0.001 ;$ M. balthica $r^{2}=0.395 ; P<0.001$; Fig. 4a, b).

\section{Discussion}

In the absence of $A$. marina, increased abundances of tubebuilding polychaetes and decreased abundances of burrowing species confirm the mobility-mode hypothesis in softbottom communities, suggested by Brenchley (1982) and Posey (1987). Increased abundances of sessile species had further consequences for the benthic community, as protruding tube caps provided attachment for macroalgae and above-ground structures, like animal tubes and algae, in

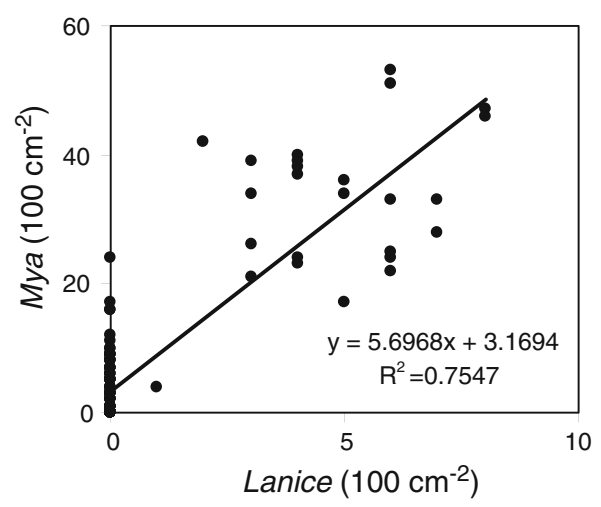

Fig. 4 Regression analysis between Lanice conchilega and spat of Mya arenaria (a) and Macoma balthica (b) within 144 samples from all experimental plots in summer 2004

turn triggered settlement of juvenile benthic species. The separate aspects of these cascading processes have already been described in the literature (lugworms inhibit tube builder, e.g. in Flach 1992; tube builder anchor algae, e.g. in Thomsen and McGlathery 2005; above-ground structures facilitate bivalve recruitment, e.g. in Cummings et al. 1996). In this study the consecutive pattern of these interactions has been triggered by the experimental large-scale and long-term exclusion of a dominant sediment destabilizing bio-engineer. It is proposed that mobility-mode interactions may go far beyond localised sediment disturbance or stabilization and involve manifold aspects of bio-engineering. In the first part of the discussion, the benthic community
Fig. 3 Abundances of Lanice conchilega (a), green algal frequency (b) and abundances of Mya arenaria (c) and Macoma balthica $(\mathbf{d})$ on experimental plots in summer 2004 (shown are means and SE $(n=6)$; Black = exclusion;

Grey = control;

White $=$ ambient; asterisks indicate significant different treatments)
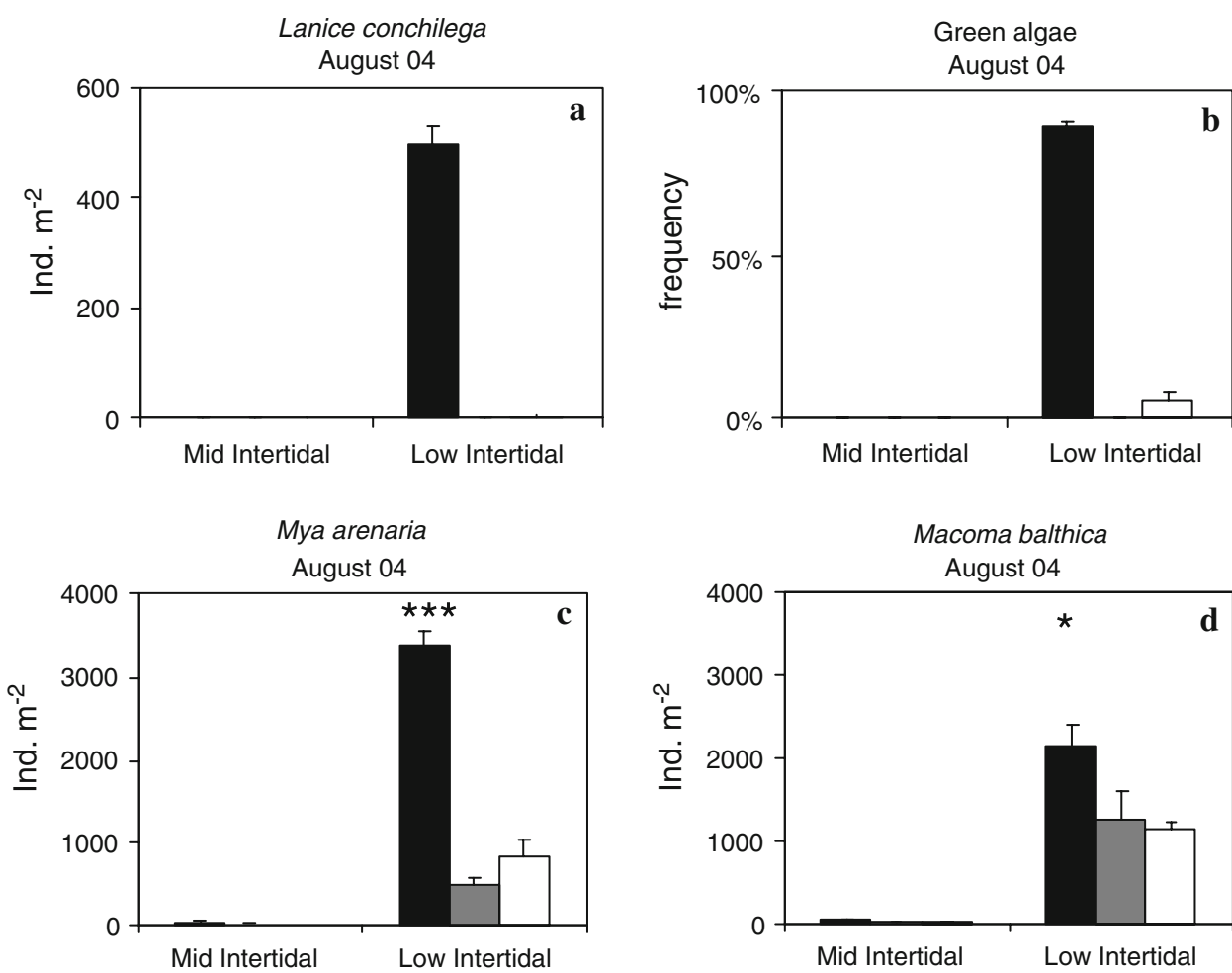
developments on experimental plots in the course of the experiment will be discussed separately. In order to assess the underlying mechanisms this part is augmented by additional information on the ecology and the engineering effects of involved species from the literature. In the second part of the discussion these findings are put into a wider ecological context. It is suggested that spatial competition of sediment stabilizing and destabilizing bio-engineers is a characteristic element of benthic community dynamics.

Lugworms inhibit tube-building polychaetes

Arenicola marina was found to have significant positive effects on the abundance of several other meio- and macrobenthic species around the burrow (Reise and Ax 1979; Lackschewitz and Reise 1998), while sedentary species near the surface were negatively affected (Flach and de Bruin 1993; Zipperle and Reise 2005). Negative effects of this bioturbator on tube-building species were mainly attributed to unstable conditions in the presence of lugworm feeding activity (Brey 1991; Flach 1992). This is generally supported by observations on the experimental plots in this study: species with permanent tubes or burrows were more abundant on lugworm exclusion plots, while abundances of free-burrowing species decreased (see also Volkenborn and Reise 2007). However, it is suggested that also other factors than direct and localised disturbance by bioturbation need to be considered to explain the differential abundances on experimental plots.

Polydora cornuta was not significantly affected by lugworm presence/absence in April, though abundances at mid intertidal were threefold in the absence of A. marina. When sampled later with a finer mesh in August, abundances of $P$. cornuta were significantly higher on lugworm exclusion than on lugworm plots. Presumably, juvenile $P$. cornuta had settled near the adults in early summer. Protruding tubes of $P$. cornuta were composed of very fine material (personal observation). A. marina was found to inhibit the accumulation of fine particles in surface sediments on experimental plots (Volkenborn et al. 2007a, b). Thus, $P$. cornuta may have taken benefit from a higher availability of fine particles in the absence of A. marina. Overall, lugworm effects on abundances of $P$. cornuta were moderate and a combined effect of direct disturbance and biogenic habitat transformations is suggested.

Lanice conchilega became established almost exclusively on lugworm exclusion plots in the low intertidal zone. Lugworm abundances were generally low on lugworm plots in 2004 (5-10 ind. $\mathrm{m}^{-2}$ on experimental plots in the low intertidal area; for details see Volkenborn and Reise 2006), when L. conchilega settled on experimental plots. Thus, disturbance by lugworm feeding activities is unlikely to be the only reason for the establishment of the tube-dweller. A plausible explanation for the observed pattern is a cumulative change in sediment properties in the course of 2 years. It is left to speculation which characteristics actually attracted $L$. conchilega, but a combined effect of increased organic matter, more fine particles and more microphytobenthos on lugworm exclusion plots (Volkenborn et al. 2007a, b) is very likely. Since colonisation of $L$. conchilega was found to be facilitated by the presence of already existing Lanice tubes (Strasser and Pieloth 2001; Callaway 2003), abundances of L. conchilega may continue to increase on lugworm exclusion plots in the low intertidal.

Polychaete tubes anchor algal tufts

In both years of this study, ephemeral growth of tuft-forming algae was found on experimental plots. Most of these diatom, green and red algal tufts were attached to protruding polychaete tubes. On dynamic intertidal sands, where substrate for algal attachment is scarce, polychaete tube caps may significantly facilitate algal growth by providing anchorage (Woodin 1977; Thomsen and McGlathery 2005). On lugworm exclusion plots algal biomass reached values of up to $20 \mathrm{~g}$ dry weight $\mathrm{m}^{-2}$. During and after the growth season, algae were partly buried in the sediment. This incorporation of organic material presumably contributed to the organic enrichment of lugworm exclusion plots.

Biogenic above-ground structures increase settlement of drifting juvenile macrofauna

Juvenile abundances of $M$. arenaria and $M$. balthica were significantly higher on lugworm exclusion plots in both years and closely linked to the number of sediment protruding tube caps. Increased abundances of juvenile bivalves in the absence of lugworms may have been the product of inhibition by large bioturbators (Rhoads and Young 1970; Woodin 1976; Flach 1992) and of facilitation by sediment stabilisers and animal tubes (Cummings et al. 1996; Thomsen and McGlathery 2005; Bolam and Fernandes 2003). Strong response of juvenile bivalves in 2004, when lugworm abundances were rather low at the study site (510 ind. $\mathrm{m}^{-2}$ on control and ambient plots in the low intertidal area), suggests that inhibition by lugworm disturbance and feeding is unlikely to be the sole reason for the observed pattern. Presumably, above-ground structures, like polychaete tubes and anchored algae, provided attachment for young bivalves with byssus threads and thus facilitated their settlement. The strong correlation of juvenile bivalves numbers and protruding tube caps of $L$. conchilega within $100 \mathrm{~cm}^{2}$ samples in 2004 does not prove this causal relationship, but based on the ecology of both bivalve species, localised increased settlement of M. balthica and Mya 
arenaria in the presence of above-ground structures is very likely. Postlarval drift is a common phenomenon among many benthic species (see review by Butman 1987) and in the intertidal zone of the Wadden Sea, spat of the bivalves M. balthica, M. arenaria and others change their intertidal position by postlarval byssus drifting (Armonies 1994). In these bivalves, mucus threads several times the length of the animals enable them to become effectively transported in the water column by currents (Sigurdsson et al. 1976; Beukema and de Vlas 1989; Armonies 1996). Due to these secondary redistributions species are able to colonise habitats which are more suitable for subsequent life stages (Armonies 1994; Strasser 2002; Hiddink 2003). After having burrowed between polychaete tubes, the juvenile bivalves may additionally find shelter from predation and the likelihood of re-suspension may be reduced (Armonies and Hellwig-Armonies 1992).

\section{Mobility-mode hypothesis and benthic bio-engineering}

The results from this study resemble the mobility-mode hypothesis (reviewed by Posey 1987) that sediment destabilizing organisms (bioturbators) inhibit sedentary and tube-building species and vice versa. Ecosystem engineering by lugworms resulted in the maintenance of permeable, low-organic sand (Volkenborn et al. 2007a). In the course of the experiment, bio-engineering by sediment stabilizing species took over on lugworm exclusion plots and facilitated other species that rely on stable sediment or on the presence of above-ground structures. Based on relevant literature, it is suggested that bio-engineering by several species which took advantage from the exclusion of an abundant sediment destabilizer have opposite effects on the sedimentary habitat. Tube-building ploychaetes were found to increase fine particle content (Bolam and Fernandes 2003; Rabaut et al. 2007). The incorporation of algal material results in an organic enrichment of the sediment with further consequences for the benthic community (Thiel and Watling 1998). Thus, engineering by these species potentially amplified the effects of lugworm absence. In 2004, sediment permeability on experimental exclusion plots in the low intertidal had fallen below the critical value where lugworms can thrive (Volkenborn et al. 2007b). The contrasting effects of both functional types of benthic bio-engineers suggest that mutual exclusion may not only be a product of localised disturbance or sediment binding, but involve long-lasting, sediment-mediated processes. In this way, even small tube-building species, such as $P$. cornuta, may contribute to the alteration of the sediment, ultimately reducing the habitat suitability for large burrowers, such as A. marina.

Results from this large-scale, long-term field experiment also indicate that the effects of benthic bio-engineering are conditional, dependent upon sediment type and supply of colonisers. Similar emergent patterns occurred in the 2 years of observation but different species were involved in the processes: $P$. cornuta and $L$. conchilega as tube builders, tufts of diatoms and green algae as an epibenthic cover and juveniles of M. balthica and Mya arenaria as drifting macrofauna. Moreover, these contingent events occurred only at mid-tide level in the first year and only at low-tide level in the second year but were not observed at low-tide level in the first year or at mid-tide level in the second year. The combination of variable environmental conditions and a variable supply of colonisers may account for conditional outcome of benthic engineering in time and space (i.e. Menge and Sutherland 1987; Lotze et al. 2000; Norkko et al. 2006).

\section{Conclusion}

On intertidal flats stabilizing and destabilizing sedimentengineers have profound, but spatially and temporally variable effects on the sedimentary habitat and on benthic community dynamics. This study gives experimental evidence that spatial competition between both types of bio-engineers may exist, as both types maintain the habitat suitable for their own and the less suitable for the functionally different form. Cumulative effects of their biogenic activities and cascading effects in the benthic community may explain the persistence of patches, dominated by species of one functional group.

Acknowledgments We gratefully acknowledge Heike Lotze and Helmut Hillebrand for advice in statistical analysis. Tjeerd Bouma and two anonymous reviewers are thanked for valuable comments on the manuscript. The study was supported by the Alfred Wegener Institute for Polar and Marine Research. Additional funding during preparation of this manuscript was provided by the German Ministry for Education and Research and the State of Bremen through funding of the project NEBROC. The experiment is a contribution to the European Network of Excellence on Marine Biodiversity and Ecosystem Functioning (MarBEF).

\section{References}

Armonies W (1994) Drifting meio- and macrobenthic invertebrates on tidal flats in Königshafen: a review. Helgol Meeresunters 48:299-320

Armonies W (1996) Changes in distribution patterns of 0-group bivalves in the Wadden Sea: byssus-drifting releases juveniles from the constrains of hydrography. Neth J Sea Res 35:323-334

Armonies W, Hellwig-Armonies M (1992) Passive settlement of Macoma balthica spat on tidal flats of the Wadden Sea and subsequent migration of juveniles. Neth J Sea Res 29:371-378

Austen I (1994) The surficial sediments of Königshafen—variations over the past 50 years. Helgol Meeresunters 48:163-171

Beukema JJ (1976) Biomass and species richness of the macro-benthic animals living on the tidal flats of the Dutch Wadden Sea. Neth J Sea Res 10:236-261 
Beukema JJ, de Vlas J (1989) Tidal-current transport of thread-drifting postlarval juveniles of the bivalve Macoma balthica from the Wadden Sea to the North Sea. Mar Ecol Prog Ser 52:193200

Bolam SG, Fernandes TF (2003) Dense aggregations of Pygospio elegans (Claparede): effect on macrofaunal community structure and sediments. J Sea Res 49:171-185

Brenchley GA (1981) Disturbance and community structure: an experimental study of bioturbation in marine soft-bottom environments. J Mar Res 39:767-790

Brenchley GA (1982) Mechanisms of spatial competition in marine soft-bottom communities. J Exp Mar Biol Ecol 60:17-33

Brey T (1991) The relative significance of biological and physical disturbance: an example from intertidal and subtidal sandy bottom communities. Estuar Coast Shelf Sci 33:339-360

Butman C (1987) Larval settlement of soft-sediment invertebrates: the spatial scales of patterns explained by active habitat selection and the emerging role of hydrodynamical processes. Oceanogr Mar Biol Ann Rev 25:113-165

Cadée GC (1976) Sediment reworking by Arenicola marina on tidal flats in the Dutch Wadden Sea. Neth J Sea Res 10:440-460

Callaway R (2003) Juveniles stick to adults: recruitment of the tubedwelling polychaete Lanice conchilega (Pallas, 1766). Hydrobiol 503:121-130

Cummings VJ, Pridmore RD, Thrush SF, Hewitt JE (1996) Effect of the spinoid polychaete Boccardia syrtis on the distribution of juveniles Macoma balthica (Bivalvia: Tellinacea). Mar Biol 126:91-98

Flach EC (1992) Disturbance of benthic infauna by sediment-reworking activities of the lugworm Arenicola marina. Neth J Sea Res 30:81-89

Flach EC, de Bruin W (1993) Effects of Arenicola marina and Cerastoderma edule on distribution, abundance and population structure of Corophium volutator in Gullmarsfjorden western Sweden. Sarsia 78:105-118

Gallagher ED, Jumars PA, Trueblood DD (1983) Facilitation of softbottom benthic succession by tube-builders. Ecology 64:12001216

Gutierrez JL, Jones CG, Strayer DL, Iribarne OO (2003) Mollusks as ecosystem engineers: the role of shell production in aquatic habitats. Oikos 101:79-90

Hiddink JG (2003) Modelling the adaptive value of intertidal migration and nursery use in the bivalve Macoma balthica. Mar Ecol Prog Ser 252:173-185

Huettel M (1990) Influence of the lugworm Arenicola marina on porewater nutrient profiles of sand flat sediments. Mar Ecol Prog Ser 62:241-248

Kristensen E, Blackburn TH (1987) The fate of organic carbon and nitrogen in experimental marine sediment systems: influence of bioturbation and anoxia. J Mar Res 45:231-257

Lackschewitz D, Reise K (1998) Macrofauna on flood delta shoals in the Wadden Sea with an underground association between the lugworm Arenicola marina and the amphipod Urothoe poseidonis. Helgol Meeresunters 52:147-158

Lawton JH, Jones CG (1993) Linking species and ecosystems. Trends Ecol Evol 8:311-313

Lotze HK, Worm B, Sommer U (2000) Propagule banks, herbivory and nutrient supply control population development and dominance patterns in macroalgal blooms. Oikos 89:46-58

Luckenbach MW (1986) Sediment stability around animal tubes: the roles of hydrodynamic processes and biotic activity. Limnol Oceanogr 31:719-787

Menge BA, Sutherland JP (1987) Community regulation: variation in disturbance, competition, and predation in relation to gradients of environmental stress and recruitment. Am Nat 130:730-757
Norkko A, Hewitt JE, Thrush SF, Funnell GA (2006) Conditional outcomes of facilitation by a habitat-modifying subtidal bivalve. Ecology 87:226-234

Peterson CH (1977) Competitive organization of the soft-bottom macrobenthic communities of southern California lagoons. Mar Biol 43:343-359

Posey MH (1986) Changes in a benthic community associated with dense beds of a burrowing deposit feeder, Callianassa californiensis. Mar Ecol Prog Ser 31:15-22

Posey MH (1987) Influence of relative mobilities on the composition of benthic communities. Mar Ecol Prog Ser 39:99-104

Rabaut M, Guilini K, Van Hoey G, Vincx M, Degraer S (2007) A bioengineered soft-bottom environment: the impact of Lanice conchilega on the benthic species-specific densities and community structure. Estuar Coast Shelf Sci 75:525-536

Reise K (1985) Tidal flat ecology. Springer, Berlin, p 191

Reise K (1991) Mosaic cycles in the marine benthos. In: Remmert H (ed) The mosaic-cycle concept of ecosystems. Springer, Berlin, pp 61-82

Reise K (2002) Sediment mediated species interactions in coastal waters. J Sea Res 48:127-141

Reise K, Ax P (1979) A meiofaunal 'Thiobios' limited to the anaerobic sulfide system of marine sand does not exist. Mar Biol 54:225237

Rhoads DC (1974) Organism-sediment relations on the muddy sea floor. Oceanogr Mar Biol Ann Rev 12:263-300

Rhoads DC, Young DK (1970) The influence of deposit feeding organisms on sediment stability and community trophic structure. J Mar Res 28:150-178

Riisgård HU, Banta GT (1998) Irrigation and deposit feeding by the lugworm Arenicola marina, characteristics and secondary effects on the environment. A review of our current knowledge. Vie Milieu 48:243-257

Siebert T, Branch GM (2006) Ecosystem engineers: interactions between eelgrass Zostera capensis and the sandprawn Callianassa kraussi and their indirect effects on the mudprawn Upogebia africana. J Exp Mar Biol Ecol 338:253-270

Sigurdsson JB, Titman CW, Davies PA (1976) The dispersal of young post-larval bivalve molluscs by byssus threads. Nature 262:386387

Strasser M (2002) Reduced epibenthic predation on intertidal bivalves after a severe winter in the European Wadden Sea. Mar Ecol Prog Ser 241:113-123

Strasser M, Pieloth U (2001) Recolonization pattern of the polychaete Lanice conchilega on an intertidal sand flat following the severe winter of 1995/1996. Helgol Mar Res 55:176-181

Thayer CW (1983) Sediment-mediated biological disturbance and evolution of marine benthos. In: Tevez MJS, Mc Call PL (eds) Benthic communities. Plenum Press, New York, pp 479-625

Thiel M, Watling L (1998) Effects of green algal mats on infaunal colonization of a New England mud flat-long-lasting but highly localized effects. Hyrobiologia 375:177-189

Thomsen MS, McGlathery K (2005) Facilitation of macroalgae by the sedimentary tube forming polychaete Diopatra cuprea. Estuar Coast Shelf Sci 62:63-73

van Wesenbeeck BK, van de Koppel J, Herman PMJ, Bakker JP, Bouma TJ (2007) Biomechanical warfare in ecology; negative interactions between species by habitat modification. Oikos 116:742750

Volkenborn N, Reise K (2006) Lugworm exclusion experiment: responses by deposit feeding worms to biogenic habitat transformations. J Exp Mar Bio Ecol 330:169-179

Volkenborn N, Reise K (2007) Effects of Arenicola marina on polychaete functional diversity revealed by large-scale experimental lugworm exclusion. J Sea Res 57:78-88 
Volkenborn N, Hedtkamp SIC, van Beusekom JEE, Reise K (2007a) Effects of bioturbation and bioirrigation by lugworms (Arenicola marina) on physical and chemical sediment properties and implications for intertidal habitat succession. Estuar Coast Shelf Sci 74:331-343

Volkenborn N, Polerecky L, Hedtkamp SIC, van Beusekom JEE, Beer DDe (2007b) Bioturbation and bioirrigation extend the open exchange regions in permeable sediments. Limnol Oceanogr 52:1898-1909

Wilson WH (1981) Sediment-mediated interactions in a densely populated infaunal assemblage: the effects of the polychaete Abarenicola pacifica. J Mar Res 39:735-748
Woodin SA (1976) Adult-larval interactions in dense infaunal assemblages: patterns of a bundance. J Mar Res 34:25-41

Woodin SA (1977) Algal "gardening" behavior by nereid polychaetes: effects on soft-bottom community structure. Mar Biol 44:39-42

Woodin SA (1981) Disturbance and community structure in a shallow water sand flat. Ecology 62:1052-1066

Woodin SA, Jackson JBC (1979) Interphyletic competition among marine benthos. Am Zool 19:1029-1043

Zipperle A, Reise K (2005) Freshwater springs on intertidal sand flats cause a switch in dominance among polychaete worms. J Sea Res $54: 143-150$ 